\title{
Hungarian establishment now opposes hydroelectric project \\ London
}

THE Hungarian Academy of Sciences has asked the government for permission to publish its three reports on the probable environmental effect of the GabcikovoNagymaros hydroelectric project. This is the latest in a sequence of events that, since the conference of the Hungarian Socialist Workers' Party two months ago, has transferred open opposition to the scheme from fringe environmental organizations to establishment bodies.

The project, which involves the diversion of the Danube through Slovakia, north from its present channel, and the construction of two major 'peak-hour' hydroelectric plants at Gabcikovo in Slovakia and Nagymaros in Hungary, was originally intended as a joint Czechoslovak-Hungarian undertaking. But three years ago when the Hungarian side deferred its part due to lack of money, the Austrians, who had been blocked by their own 'greens' from building a similar peakhour plant at Hainberg, offered to finance the Hungarian part of the structure.

By this time, there was a growing groundswell of opinion against the dam in Hungary (the first two highly critical academy reports had already been drawn up). The then Hungarian leader, Mr Janos Kadar, preferred to use quiet diplomacy with the Czechoslovak side, and, when the latter proved unwilling to cancel, to plead poverty. The Austrian involvement, in effect, called his bluff, and construction began on the Hungarian side too. All that the academy could do at that stage was to negotiate additional funding to offset the environmental threat.

The party conference of 22-23 May 1988 brought a change of leadership. The day after Kadar was replaced by the incumbent prime minister, $\mathrm{Mr}$ Karoly Grosz, the recently formed 'official' Hungarian Society for the Protection of the Environment issued a call for a new appraisal of the economic and environmental costs of the scheme. Four days later, there was a demonstration in Budapest against Austrian involvement. Next, a member of parliament, Mr Zoltan Kiraly, called for a full parliamentary debate into the dam. This will take place during the autumn, and the preparatory briefing of MPs has now begun, including, significantly, figures on the cost of cancelling the whole project, or of completing the power station at Nagymaros without the projected dam.

In mid-July, the president of the Hungarian Academy of Sciences, Academician Ivan T. Berend, met Dr Bela Liptak, head of the Foundation for the Protection of the Hungarian Environment, an association of expatriate Hungarian scientists based

\section{Dangers of more debris in space}

\section{Paris}

THE European Space Agency (ESA), in a report to be published later this year, has been taking a look at the problems of space debris which have recently been worrying the US Congress (Nature 334, 188; 1988).

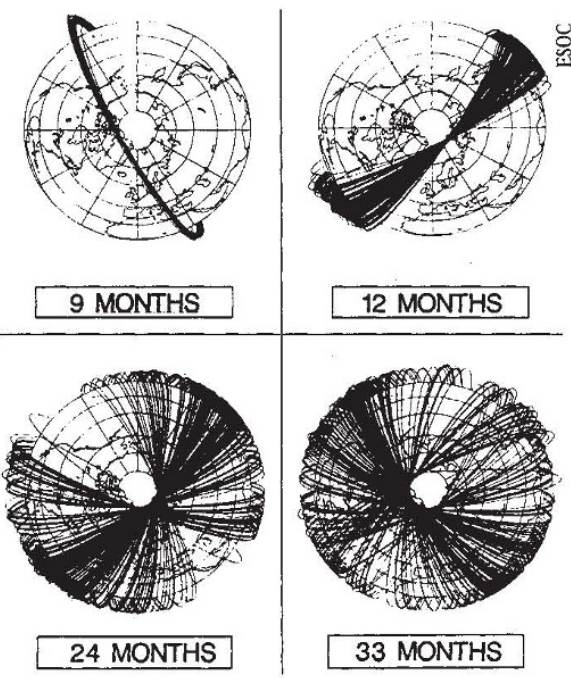

Computer simulation of the evolution of fragment orbits from an explosion.
On the basis of computer simulation, ESA's working group on space debris estimates that there are between 30,000 and 70,000 small fragments orbiting the Earth, in addition to the 7,000 larger objects currently being tracked by the United States and the Soviet Union.

The working group was set up in 1986, under the chairmanship of Walter Flury, to look at collision hazards in the geostationary orbit, $36,000 \mathrm{~km}$ above the Earth, and the risks to spacecraft and manned missions in lower orbits. Of particular concern to ESA are the Hubble Space Telescope and the Hipparcos astronomical satellite, which are likely to suffer interference from light refracted off small particles, as well as the risks of damage through collision.

According to ESA's estimates, the Hubble Space Telescope will run a one per cent risk of colliding with a "large piece of junk", over $10 \mathrm{~cm}$ in diameter, during its 17-year lifetime. But collision with smaller debris, for which no figures are given, would also be serious. A pea-sized fragment orbiting at $5 \mathrm{~km}$ per second "could shatter a $\$ 100$ million satellite", said an ESA spokeswoman. in the United States. Together they wrote a letter to the Hungarian government, setting out the case against the dam. This letter has since been heavily attacked by the Slovak daily Pravda, which claimed that Liptak's figure contradicted those of the Hungarian and Czechoslovak specialists. The figures, however, come from the unpublished academy reports, while according to Kiraly, members of the Slovak Academy are becoming increasingly worried that the Nagymaros dam will drown or swamp much of Slovakia's best agricultural land.

Vera Rich

\section{Japan subsidizes superconductors}

Tokyo

JAPAN's Ministry of International Trade and Industry (MITI) is planning to double government subsidies for the International Superconductivity and Technology Center, established in January with massive funding from the private sector (Nature 331, 105; 1988). But, despite an enviable budget, there are still few foreign companies willing to join the centre.

Membership of the centre for companies comes in two forms: 'general' members can gain access to an information centre and symposia for a down-payment of $¥ 2$ million $(\$ 15,000)$ and an annual subscription of the same amount, while 'special' members must fork out an additional $¥$ 100 million $(\$ 750,000)$ plus $¥ 12$ million a year to join the centre's research laboratory which is due to open in Tokyo in October.

More than a hundred companies have joined the information centre and 45 have signed up for the laboratory, bringing in more than $¥ 5,200$ million ( $\$ 39$ million) in the first year of operation. In addition, MITI has provided the centre with about $¥ 500$ million in subsidies in this fiscal year and the ministry plans to double this to about $¥ 1,000$ million in fiscal year 1989 , according to Professor Shoji Tajaka who will head the research laboratory. MITI will submit a budget request for the subsidies to the Ministry of Finance at the end of this month. But only five foreign companies, four from the United States and one from Britain, have joined the information centre and none has joined the research laboratory.

Apart from cost, Tanaka thinks that problems over patents are deterring participation of foreign companies. The 45 Japanese companies that have joined have spent months hammering out an agreement on how to deal with this issue. Tanaka expects the agreement to be drafted by next month and it will then be translated into English and provided to potential foreign participants.

David Swinbanks 